\title{
Financial inclusion, corporate social responsibility and customer loyalty in the banking sector in Vietnam
}

\author{
Duc Hong Vo* \\ The CBER - Research Centre in Business, Economics and Resources, \\ Ho Chi Minh City Open University, Ho Chi Minh City, Vietnam \\ duc.vbong@ou.edu.vn \\ ORCID 0000-0001-7823-0349 \\ *Corresponding author
}

Loan Thi-Hong Van

School of Advanced Study, Ho Chi Minh City Open University,

Ho Chi Minh City, Vietnam

loan.vth@ou.edu.vn

ORCID 0000-0003-0118-3884

\section{Luong Thi-Huyen Dinh}

Sacombank, Vietnam

buyenluongdinbthi@gmail.com

\section{Chi Minh Ho}

The CBER - Research Centre in Business, Economics and Resources, Ho Chi Minh City Open University, Ho Chi Minh City, Vietnam chi.bm@,ou.edu.vn

ORCID 0000-0002-6400-185X

Abstract. The banking sector in Vietnam is under enormous pressure today due to competition arising from the integration of Vietnamese economy into the world economy. Survival and success of this sector significantly depend on customer loyalty which has mostly been built on the recognition of banks' social responsibility and their provision of inclusive services, generally known as financial inclusion. The recognition of social responsibility from the banking sector and its strategy on financial inclusion has largely been ignored in current literature, in particular for Vietnam. This study has been conducted to examine the impact of corporate social responsibility (CSR), financial inclusion inter alia, on customer loyalty in the banking sector in Vietnam. The pyramid model is utilized in this paper, including various CSR factors/attributes such as philanthropic responsibility, ethical responsibility, legal responsibility, economic responsibility, customers-centric strategy and bank reputation. A sample of 368 responses to the

Received:

December, 2019 1st Revision: August, 2020

Accepted:

December, 2020 10.14254/20718330.2020/13-4/1 
well-defined questionnaires has been collected from the commercial banks in Vietnam in 2019. The structural equation modelling is utilized. The findings from this paper indicate that philanthropic responsibility of the banking sector has the most substantial impact on customer loyalty, followed by customer-centric strategy. Improving the aspects of CSR programs, in particular customer-centric strategy, will lead to improved extent of financial inclusion which currently attracts attention of Vietnamese government and practitioners. Doing so will improve the reputation of banks and enhance customer loyalty, thus preparing banks for competition in the near future.

Keywords: financial inclusion, corporate social responsibility, customer loyalty, structural equation modelling, Vietnam.

JEL Classification: L26, L69, M14

\section{INTRODUCTION}

The concept of corporate social responsibilities (CSR) has been an integral part of business operations since its inception. Initially, it has been considered as a mechanism to fulfil social responsibility of corporations. However, firms are increasingly recognizing CSR as a channel for profit maximization. Investment in CSR has been increasing significantly in the recent years, in particular in emerging markets. Possible impacts of CSR on the performance includes higher market value and improved financial performance.

The effect of customer loyalty on firm performance has been extensively examined. Intuitively, increasing CSR activities are expected to positively impact customer loyalty. However, empirical studies have failed to produce consistent results in this regard. Perez and Rodriguez del Bosque (2013) decomposed CSR into three dimensions and examined their impacts on customers in Spain. They found that perception of customer-centric CSR initiatives positively affects recommendation to new customers and repurchase behaviours. Carrigan and Attalla (2001), using focus group discussions, found no evidence suggesting ethical conduct of companies translates into desirable customer purchasing behaviours. In Thailand, analyzing the survey sample of 275 bank customers, Mandhachitara and Poolthong (2011) confirmed the existence of a strong and positive association between CSR and attitudinal loyalty, with perceived service quality mediating the relationship. Berens et al. (2005) consider the effect of corporate brand dominance on the relationship between corporate associations and product evaluations. The results show that with both consistent branding and endorsed strategy, CSR associations do not exert a positive influence on customer product attitudes.

In Vietnam, CSR is becoming more popular. Local Vietnamese firms have started paying attention and actively implementing CSR programs recently. Such programs are generally considered as a channel through which companies can promote their professional images and social responsibilities (Tran Anh Phuong, 2017). The banking sector plays a leading role in constructing and implementing various CSR programs by providing more inclusive services in order to enhance customer loyalty, for example, Sacombank, ACB and many others.

However, there have been very few studies with the focus on CSR and e inclusive provision of products and services within the banking sector in Vietnam. In particular, to the best of our knowledge, no study has been conducted to investigate the impact of CSR programs with the focus on the aspect of financial inclusion on customer loyalty in the banking sector in Vietnam. Financial inclusion is generally considered 
as the process which is developed to ensure that access to financial services is available and affordable to vulnerable groups, such as disadvantaged segments and low-income groups (Van et al., 2019, 2020; Nguyen et al., 2020). The banking sector has been playing and contributing significantly to economic growth and development of Vietnam, an emerging market in the Southeast Asian region.

The study is organized as follows. Following this introduction, Section 2 presents a literature review on CSR and its constructs. Research hypotheses are then developed in Section 3. Section 4 discusses the research methodology, including both qualitative and quantitative techniques. The empirical results are presented in Section 5, followed by concluding remarks and implications in Section 6 of the paper.

\section{LITERATURE REVIEW}

\subsection{Corporate social responsibility}

Corporate social responsibility (CSR) is defined as "the obligation of traders to pursue policies to make decisions or to take necessary actions regarding goals and values for society" (Bowen, 1953). The CSR is generally considered a firm commitment from businesses to contribute to sustainable economic development by working with all stakeholders, including employees, local communities and the society (World Bank, 2001). Its engagement is usually manifested using various business activities (Kotler and Lee, 2005). From a different perspective, CSR sets a minimum behavioural standard which aims to provide no harms to stakeholders.

Studies on CSR have pointed out that CSR is a multidimensional structure, and that its various constructs are dependent upon their context (Galbreath and Shum, 2012; Jamali, 2008). For instance, Salmones et al. (2005) consider that CSR consists of three different aspects: economic responsibility, ethicallegal and charitable aspects. From a different perspective, Gonzalez-Rodriguez et al. (2015) assert that the concept of CSR is established based on common, present and accepted viewpoints. Van Marrewijk (2003), on the other hand, conclude that CSR refers to corporate activities as the inclusion of social and environmental concerns in business activities and during interactions with the stakeholders. The most commonly accepted CSR constructs come from Caroll (1991). The author argues that the concept of CSR should be framed in such a way that can capture an entire range of business responsibilities. On this basis, the pyramid of CSR is developed, including four constructs/responsibilities as below.

First, an economic responsibility refers to the ultimate goal of maximizing profits from any business. This goal is considered as a primary motive for entrepreneurship. Second, legal responsibility refers to the set of laws and regulations that corporations are expected to comply as the basis and grounding rules. A social contract is established in which firms must pursue economic targets within the framework of the law. Third, ethical responsibility embraces business practices that are prohibited by the members of the society where businesses operate. These practices may not be regulated in any law or regulations. It embodies the standards and norms that reflect a concern for what the community deems as fair. Fourth, a philanthropic responsibility consists of actions in response to society's expectation of businesses being good corporate citizens. The primary examples include humanitarian or charitable activities. The difference between philanthropic responsibility and ethical responsibility is that the former is not expected in a moral sense. Philanthropic actions from business organizations are expected from society. However, the business image would not be deteriorated without them. 


\subsection{Corporate reputation and customer loyalty}

Reputation refers to a collective term referring to all stakeholders' view of corporate reputation, including identity and image. It is the overall estimation of an organization based on its past actions and future behaviour. Reputation is generally considered one of the most valuable assets in organizations. Reputation is an intangible asset. Findings from various studies have shown that a good reputation increases corporate worth and provides a sustained competitive advantage. A good reputation can lead to numerous strategic benefits such as lowering costs, attracting customers, allowing firms to charge premium prices and increasing profitability.

In addition, customer loyalty represents the willingness to continue buying products and services (Chaudhuri and Holbrook, 2001). Oliver (1999) refers to loyalty as customer impression on the brand, which will create a competitive advantage for businesses. Customers will be willing to pay more for the brand they love because of the value they perceive from the product or service. Loyal customers are also willing to spend time and money searching for their favourite brands and are less responsive to promotions of competitors.

\section{RESEARCH HYPOTHESES}

\subsection{Corporate social responsibility and customer loyalty}

Research hypotheses between five distinct attributes of the CSR and customer loyalty are developed.

First, findings from many studies confirm a positive relationship between philanthropic responsibility, brand image and customer loyalty (Yusof et al., 2015; Wul et al., 2014; Khan et al., 2014). We consider that charity-related activities play a significant role in changing corporate images in public perception, in particular for developing countries.

H1a: Philanthropic responsibility bas a positive effect on customer loyalty

Second, many studies have been conducted to examine the relationship between ethics, trust and customer loyalty (Yusof et al., 2015; Khan et al., 2014; Wul et al., 2014; Reast, 2005; Ballester and Aleman, 2001). From these studies, trust is believed to enhance customer loyalty by inducing repeated purchases. We consider that companies that align their corporate responsibility strategy with ethical values can gain a competitive advantage.

H1b: $\quad$ Ethical responsibility has a positive effect on customer loyalty

Third, many studies have recognized corporate responsibility and fairness to public authorities as an important element of the CSR (Maignan, 2001; Salmones et al., 2005; Turker, 2009). Previous studies conclude that the extent to which banks are considered to respect the standards defined in the law positively affects customer loyalty (Pérez, 2013; Choi and La, 2013). We consider that any company has a responsibility to comply fully with the provisions of the law, to abide by the rules set forth by the regulators.

H1c: $\quad$ Legal responsibility has a positive effect on customer loyalty

Fourth, Carroll's pyramid model (1991) places economic responsibility at the end of the pyramid. This means that a business will only perform social responsibilities well when it fulfils its economic responsibilities by maximizing profits and bringing economic benefits to its stakeholders.

H1d: Economic responsibility has a positive effect on customer loyalty 
Fifth, customer-centric CSR initiatives have a significant impact on consumer behaviour and attitudes (McDonald, 2010). We consider that when customers feel enthusiastically supported by the company, they tend to return more. In the banking sector, product quality, reasonable prices, creative services, polite staff behaviour and attitudes, good customer service handling are all aspects of placing a customer in the centre.

H1e: $\quad$ Customer-centric strategy bas a positive effect on customer loyalty

\subsection{Corporate social responsibility and corporate reputation}

Corporate reputation is the result of corporate governance and behaviour. The way customers perceive CSR activities, and the quality of their relationship with the company are the important factors in determining their response (Bhattacharya et al., 2009). These arguments indicate that bank reputation as a valuable intangible asset has the potential to mediate the effects of the CRS on customer loyalty. This study uses signal theory as a framework to explain this intermediary effect, namely the relationship between CSR, bank reputation and customer loyalty. Company actions and strategic choices send signals to stakeholders who are then used to build impressions and develop attitudes and responses behaviour (Basdeo et al., 2006). CSR practices provide customers with signals of corporate prestige (Hsu, 2012), affecting their reaction to the market. We suggest that the impact of CSR awareness on loyalty is mediated by bank reputation. Based on these arguments, the following hypotheses concerning the CSR and corporate reputation are considered.
H2a: $\quad$ Pbilanthropic responsibility has a positive effect on its reputation
H2b: $\quad$ Ethical responsibility has a positive effect on its reputation
H2c: $\quad$ Legal responsibility has a positive effect on its reputation
H2d: $\quad$ Economic responsibility has a positive effect on its reputation
H2e: $\quad$ Customer-centric (inclusion) strategy has a positive effect on its reputation

\subsection{Corporate reputation and customer loyalty}

Corporate reputation is considered an important determinant of loyalty (Fombrun, 1996). Good corporate reputation helps reinforce trust and customer acquisition behaviour (Nguyen and Leblanc, 2001). The reputation of the company is a prerequisite for forming loyal customers (Bae and Cameron, 2006). As such, we believe that when a business engages or enhances its CSR, it can be greatly appreciated by customers and employees.

H3: $\quad$ Corporate reputation has a positive effect on customer loyalty

Figure 1 below present our hypotheses. 


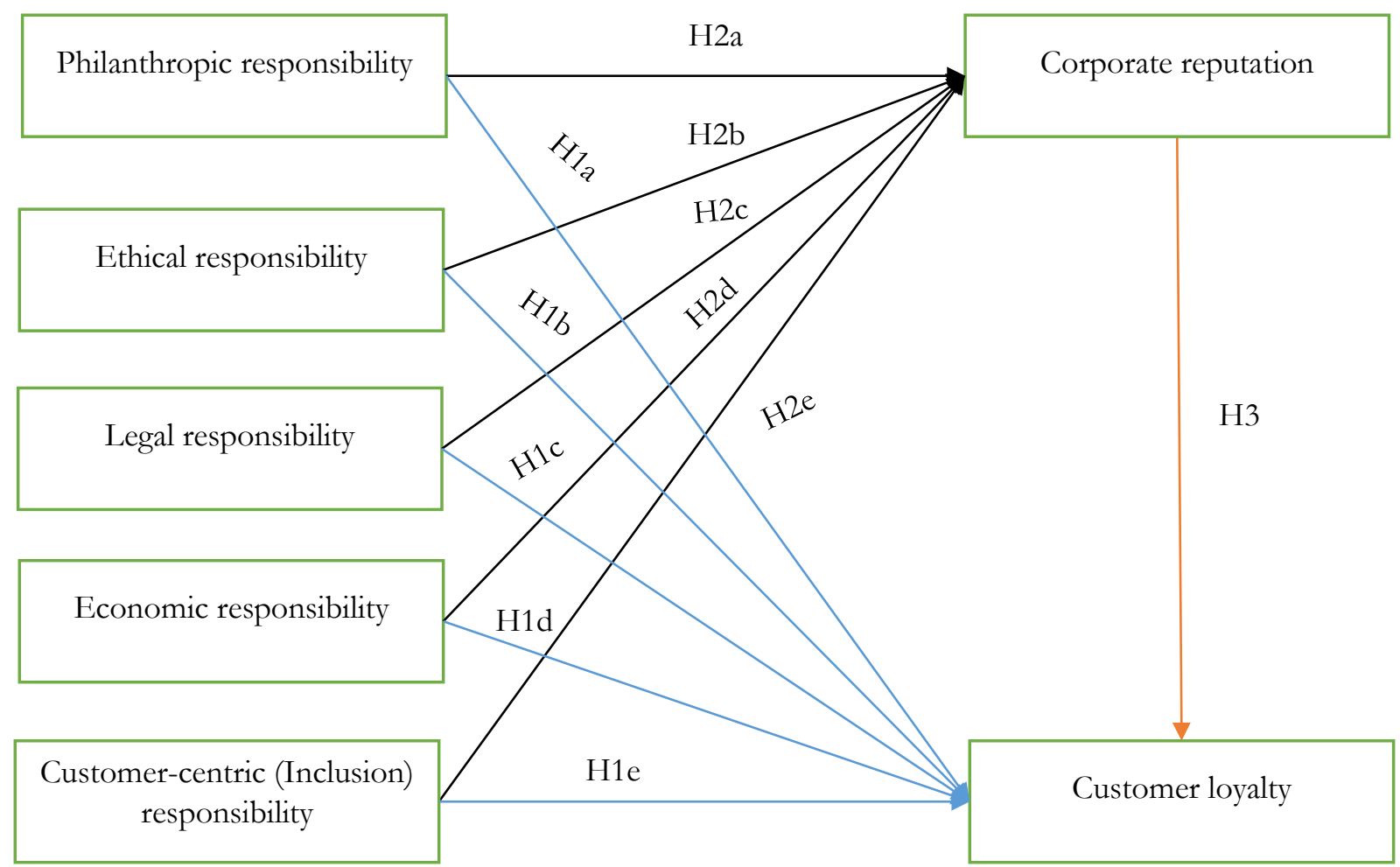

Figure 1. Research hypotheses

Source: own compilation

\section{METHODOLOGY AND DATA}

\subsection{Qualitative research}

In order to explore the potential constructs of CSR impacting customer loyalty, we employ two qualitative research techniques: face-to-face interview and focus group discussion.

- Face-to-face interviews: The interviews were conducted with five management-level staffs from four major banks in Vietnam.

- Focus group discussions: Focus group discussions were conducted with ten respondents from various industries. The purpose is for the respondent groups to assess the comprehensiveness of each construct in the scale.

\subsection{Quantitative research}

\section{Survey administration}

We conducted onsite surveys at four commercial banks in Ho Chi Minh City, Vietnam including Saigon Thuong Tin Commercial Joint Stock Bank (Sacombank), Asia Commercial Bank (ACB), Vietnam Bank for Agriculture and Rural Development (Agribank) and Vietnam Joint Stock Commercial Bank for Industry and Trade (Vietinbank). The surveys were administered between January and May 2019. About 200 questionnaires were distributed to the bank branches. Customers using any bank service at a minimum of 12 times in the past year are invited for the survey. In addition, another 200 survey questionnaires were sent to customers via email by banks' staff. We received 368 fully answered questionnaires. 


\section{Survey constructions}

All factors in the model, including Philanthropic responsibility, Ethical responsibility, Legal responsibility, Economic responsibility, Customer-centric, Corporate reputation and Customer Loyalty were surveyed on a 5 -point Likert scale ( $1=$ Strongly disagree, $5=$ Strongly agree $)$.

Table 1

Surveyed questions

\begin{tabular}{|c|c|}
\hline \multicolumn{2}{|c|}{ Philanthropic responsibility } \\
\hline TN1 & Employees of bank $\mathrm{X}$ always actively participate in charitable activities in local areas \\
\hline TN2 & Bank $\mathrm{X}$ always has a support program for education institutions \\
\hline TN3 & Bank $\mathrm{X}$ always improve the standard of living in local areas \\
\hline TN4 & You expect bank $\mathrm{X}$ to make regular contributions to charities, orphanages and welfare organizations \\
\hline TN5 & You expect bank $\mathrm{X}$ to regularly sponsor social events \\
\hline TN6 & You want bank $\mathrm{X}$ to focus not only on profits but also on social welfare \\
\hline \multicolumn{2}{|c|}{ Ethical responsibility } \\
\hline DD1 & Bank X always operates in accordance with the ethical standards and social expectations. \\
\hline DD2 & Bank X always recognize and respect new ethical standards \\
\hline DD3 & Bank $\mathrm{X}$ always prevents unethical behaviour from achieving its own goals \\
\hline DD4 & Bank X always strives to be the best bank \\
\hline DD5 & Bank X processes transactions ethically (honest with customers) \\
\hline DD6 & You expect bank $\mathrm{X}$ to focus on ethical principles rather than on economic efficiency \\
\hline DD7 & You expect bank $\mathrm{X}$ to be transparent about its products and services \\
\hline DD8 & You encourage products and services from bank $\mathrm{X}$ to maintain the ethical standard \\
\hline DD9 & You expect bank $\mathrm{X}$ to actively build trust in their customers \\
\hline \multicolumn{2}{|c|}{ Legal responsibility } \\
\hline PL1 & Bank X operates in a manner consistent with government policy and the law \\
\hline PL2 & Bank $\mathrm{X}$ always comply with regulations of different localities \\
\hline PL3 & Bank X always fulfils its legal obligations \\
\hline PL4 & Bank $\mathrm{X}$ meets the minimum legal requirements relating to products and services \\
\hline \multicolumn{2}{|c|}{ Economic responsibility } \\
\hline KT1 & Bank $\mathrm{X}$ always focus on maximizing profits \\
\hline KT2 & Bank $\mathrm{X}$ is always committed to profitability \\
\hline KT3 & Bank X has a strong competitive position \\
\hline
\end{tabular}




\begin{tabular}{|c|c|}
\hline KT4 & Bank $\mathrm{X}$ always wants to be the most profitable organization \\
\hline \multicolumn{2}{|c|}{ Customer-centric responsibility } \\
\hline TT1 & Employees of bank X are responsible for customer's complaints \\
\hline TT2 & You have high expectation for products and services from bank $\mathrm{X}$ \\
\hline TT3 & Employees of bank $\mathrm{X}$ are efficient and reliable \\
\hline TT4 & Employees of bank X resolve customer's complaints well \\
\hline TT5 & Employees of bank X must be more responsible with customer's replies \\
\hline TT6 & Employees of bank X have positive attitudes and behaviours in customer service \\
\hline TT7 & Bank X has capable personnel \\
\hline \multicolumn{2}{|c|}{ Corporate reputation } \\
\hline DT1 & Bank $\mathrm{X}$ is recognized by customers as a successful organization \\
\hline DT2 & Bank $\mathrm{X}$ is recognized by customers as a professional organization \\
\hline DT3 & Bank $\mathrm{X}$ is a very friendly organization \\
\hline DT4 & The reputation of bank $\mathrm{X}$ is highly rated \\
\hline DT5 & Bank $\mathrm{X}$ is a reliable organization \\
\hline DT6 & Bank $\mathrm{X}$ is an organization that conveys good emotions \\
\hline DT7 & Bank $\mathrm{X}$ is an admirable organization \\
\hline DT8 & Bank $\mathrm{X}$ is a respectable organization \\
\hline \multicolumn{2}{|c|}{ Customer loyalty } \\
\hline LT1 & You want to introduce bank $\mathrm{X}$ to everyone \\
\hline LT2 & You want to continue using services from bank $\mathrm{X}$ \\
\hline LT3 & You want to introduce bank $\mathrm{X}$ to colleagues, family, friends \\
\hline LT4 & Banks that display CSR are your first choices \\
\hline LT5 & You identify yourself as a loyal customer to banks that display CSR \\
\hline LT6 & You will not use services in another bank if they exist at bank $\mathrm{X}$ \\
\hline LT7 & You receive values equivalent to your money (if banks display CSR) \\
\hline LT8 & You will consider choosing banks in a couple of years. \\
\hline
\end{tabular}




\section{Data analysis}

The collected data were selected, coded and entered into SPSS and AMOS software. They were processed in the following steps:

Step 1: Descriptive statistics

Step 2: Test for internal consistency using Cronbach's alpha.

Step 3: Exploratory Factor Analysis (EFA)

Step 4: Confirmatory Factor Analysis (CFA)

Step 5: Structural equation modelling (SEM)

\subsection{Data}

52.4 per cent of the respondents in the survey are male with the mean age of above 31 . Office workers account for 38 per cent - the highest proportion of any occupation group. Respondents without college degrees have the lowest bank usage rate at 30 per cent. Graduate-level respondents record the highest rate at 41 per cent. Respondents have used bank services between 3 - 5 years (29 per cent), followed by the group with less than 1-year experience (26 per cent).

\section{RESULTS}

\subsection{Various tests}

Concerning Cronbach's alpha, a commonly accepted rule when assessing Cronbach's alpha is that if the alpha is higher than 0.7 , internal consistency is at an acceptable rate. Cronbach's alpha for all factors in the model is higher than 0.8. As such, internal consistency is validated.

Table 2

Cronbach's alpha

\begin{tabular}{|c|c|c|c|c|c|}
\hline No. & Factor & Variable & Cronbach's alpha & $\begin{array}{l}\text { Item-total } \\
\text { correlation }\end{array}$ & $\begin{array}{l}\text { Cronbach's alpha when } \\
\text { removing measures }\end{array}$ \\
\hline \multirow{6}{*}{1} & \multirow{6}{*}{$\begin{array}{l}\text { Philanthropic } \\
\text { responsibility }\end{array}$} & TNTN1 & \multirow{6}{*}{0.912} & 0.758 & 0.895 \\
\hline & & TNTN2 & & 0.733 & 0.899 \\
\hline & & TNTN3 & & 0.753 & 0.896 \\
\hline & & TNTN4 & & 0.745 & 0.897 \\
\hline & & TNTN5 & & 0.763 & 0.895 \\
\hline & & TNTN6 & & 0.767 & 0.894 \\
\hline \multirow{9}{*}{2} & \multirow{9}{*}{$\begin{array}{l}\text { Ethical } \\
\text { responsibility }\end{array}$} & TNDD1 & \multirow{9}{*}{0.933} & 0.748 & 0.926 \\
\hline & & TNDD2 & & 0.785 & 0.924 \\
\hline & & TNDD3 & & 0.745 & 0.926 \\
\hline & & TNDD4 & & 0.767 & 0.925 \\
\hline & & TNDD5 & & 0.729 & 0.927 \\
\hline & & TNDD6 & & 0.720 & 0.927 \\
\hline & & TNDD7 & & 0.756 & 0.925 \\
\hline & & TNDD8 & & 0.778 & 0.924 \\
\hline & & TNDD9 & & 0.728 & 0.927 \\
\hline \multirow{4}{*}{3} & \multirow{4}{*}{ Legal responsibility } & TNPL1 & \multirow{4}{*}{0.868} & 0.700 & 0.838 \\
\hline & & TNPL2 & & 0.706 & 0.836 \\
\hline & & TNPL3 & & 0.750 & 0.818 \\
\hline & & TNPL4 & & 0.717 & 0.831 \\
\hline \multirow{4}{*}{4} & \multirow{4}{*}{$\begin{array}{l}\text { Economic } \\
\text { responsibility }\end{array}$} & TNKT1 & \multirow{4}{*}{0.848} & 0.676 & 0.812 \\
\hline & & TNKT2 & & 0.679 & 0.810 \\
\hline & & TNKT3 & & 0.684 & 0.809 \\
\hline & & TNKT4 & & 0.707 & 0.798 \\
\hline 5 & Customer centric & KHLTT1 & 0.915 & 0.712 & 0.906 \\
\hline
\end{tabular}




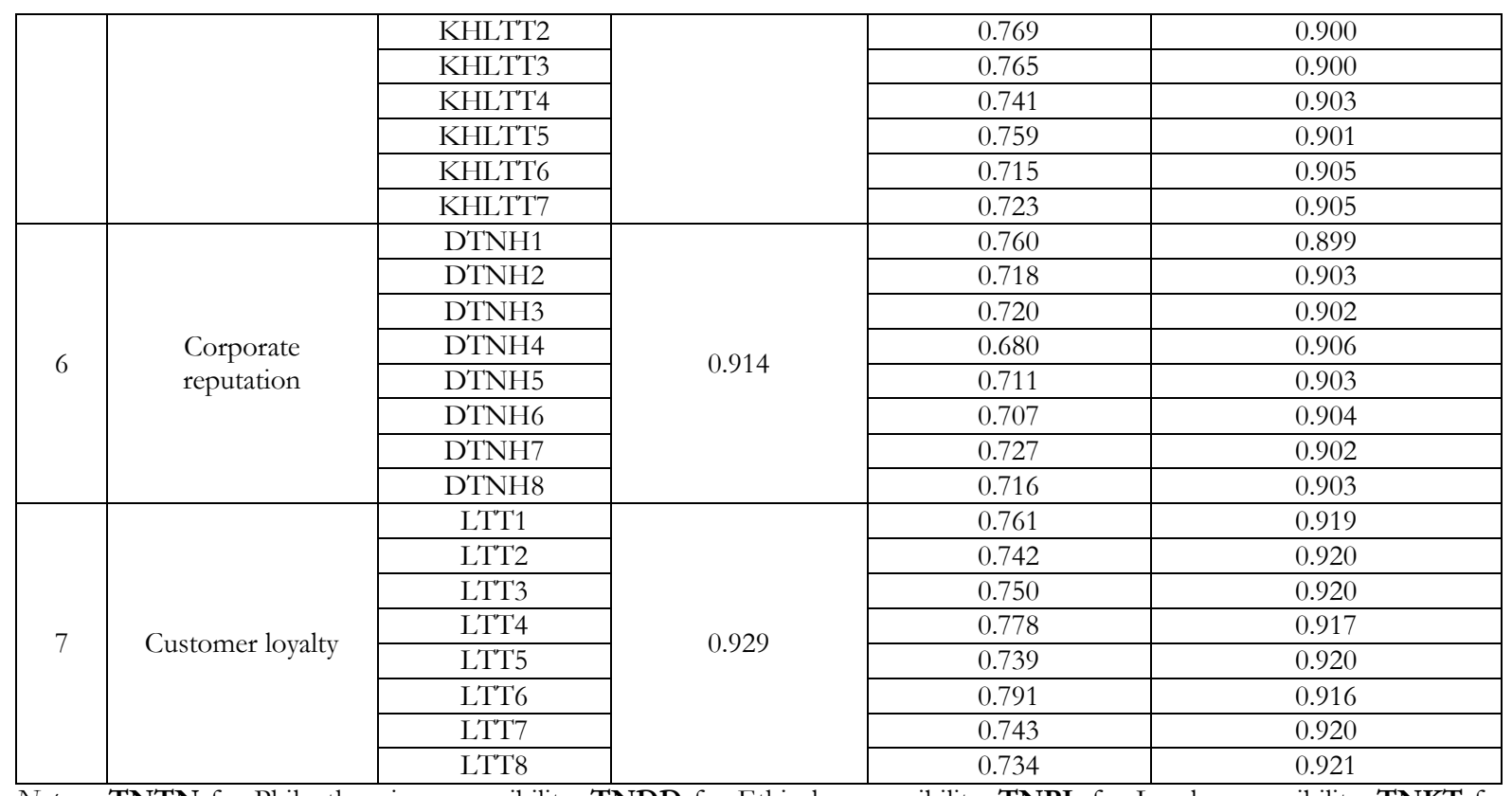

Note: TNTN for Philanthropic responsibility; TNDD for Ethical responsibility; TNPL for Legal responsibility; TNKT for Economic responsibility; KHLTT for Customer-centric responsibility; DTNH for Corporate reputation; LTT for Customer loyalty.

Source: own compilation

Table 3 presents results from the Kaiser-Meyer-Olkin (KMO) and Bartlett's test. The KMO measure of sampling adequacy is close to 1.00 , indicating that factor analysis may be useful with the collected data.

Table 3

KMO and Bartlett's test

\begin{tabular}{|c|c|c|c|}
\hline & & Condition & Conclusion \\
\hline KMO & 0.971 & $0.5 \leq \mathrm{KMO} \leq 1.0$ & Accepted \\
\hline Sig. (Bartlett testing) & 0.000 & $<0.05$ & Accepted \\
\hline Eigenvalue & 1.204 & $\geq 1.0$ & Accepted \\
\hline $\begin{array}{c}\text { \% Cumulation of } \\
\text { Eigenvalue }\end{array}$ & $61.718 \%$ & $\geq 50 \%$ & Accepted \\
\hline
\end{tabular}

Source: own compilation

Our exploratory factor analysis (EFA) analysis indicates that all factor loadings are higher than 0.65. Since factor loadings can be interpreted as standardized regression coefficients, there exists a very strong correlation between the factors and latent variables. In addition, results from the confirmatory factor analysis (CFA) confirm the consistency and validity of the factors in the model. In particular, all of the critical statistics, including Chi-square (1.117), P-value (0.007), RMSEA (0.018), CFI (0.987) and TLI (0.986), have satisfied the conditions. Moreover, the standardized weights being greater than 0.5 and statistically significant at the 5 per cent level confirm the convergent criterion. The unidirectional rule is also satisfied because the estimates are statistically different from 1, implying no correlation between the factors. We employ Joreskog's (1971) test to assess the reliability of the scale. The test consists of two criteria: (i) General reliability coefficient $(\geq 0.7)$ and (ii) Total variance extracted $(\geq 0.5)$. Results in Table 4 confirm the validity of the scale. 
Vo, H.D., Van, T.H.L, Dinh, T.H.L., Ho, M.C.
Financial inclusion, corporate social responsibility and customer loyalty in the banking sector in Vietnam

Table 4

Testing for general reliability coefficient and total variance extracted

\begin{tabular}{|c|c|c|c|c|c|c|c|}
\hline & & & $\lambda$ & $1-\lambda_{t}^{2}$ & $\lambda_{i}^{2}$ & $\begin{array}{c}\text { General } \\
\text { reliability } \\
\text { coefficient }\end{array}$ & $\begin{array}{c}\text { Total } \\
\text { variance } \\
\text { extracted }\end{array}$ \\
\hline TNDD7 & $\leftarrow$ & TNDD & 0.780 & 0.392 & 0.608 & \multirow{9}{*}{0.933} & \multirow{9}{*}{0.609} \\
\hline TNDD4 & $\leftarrow$ & TNDD & 0.796 & 0.366 & 0.634 & & \\
\hline TNDD1 & $\leftarrow$ & TNDD & 0.775 & 0.399 & 0.601 & & \\
\hline TNDD2 & $\leftarrow$ & TNDD & 0.820 & 0.328 & 0.672 & & \\
\hline TNDD9 & $\leftarrow$ & TNDD & 0.755 & 0.430 & 0.570 & & \\
\hline TNDD8 & $\leftarrow$ & TNDD & 0.810 & 0.344 & 0.656 & & \\
\hline TNDD3 & $\leftarrow$ & TNDD & 0.774 & 0.401 & 0.599 & & \\
\hline TNDD6 & $\leftarrow$ & TNDD & 0.750 & 0.438 & 0.563 & & \\
\hline TNDD5 & $\leftarrow$ & TNDD & 0.762 & 0.419 & 0.581 & & \\
\hline DTNH5 & $\leftarrow$ & DTNH & 0.741 & 0.451 & 0.549 & \multirow{8}{*}{0.914} & \multirow{8}{*}{0.570} \\
\hline DTNH1 & $\leftarrow$ & DTNH & 0.801 & 0.358 & 0.642 & & \\
\hline DTNH2 & $\leftarrow$ & DTNH & 0.750 & 0.438 & 0.563 & & \\
\hline DTNH3 & $\leftarrow$ & DTNH & 0.755 & 0.430 & 0.570 & & \\
\hline DTNH4 & $\leftarrow$ & DTNH & 0.711 & 0.494 & 0.506 & & \\
\hline DTNH8 & $\leftarrow$ & DTNH & 0.759 & 0.424 & 0.576 & & \\
\hline DTNH6 & $\leftarrow$ & DTNH & 0.746 & 0.443 & 0.557 & & \\
\hline DTNH7 & $\leftarrow$ & DTNH & 0.775 & 0.399 & 0.601 & & \\
\hline KHLTT3 & $\leftarrow$ & KHLTT & 0.801 & 0.358 & 0.642 & \multirow{7}{*}{0.916} & \multirow{7}{*}{0.608} \\
\hline KHLTT4 & $\leftarrow$ & KHLTT & 0.775 & 0.399 & 0.601 & & \\
\hline KHLTT2 & $\leftarrow$ & KHLT'T & 0.808 & 0.347 & 0.653 & & \\
\hline KHLTT5 & $\leftarrow$ & KHLT'T & 0.802 & 0.357 & 0.643 & & \\
\hline KHLTT7 & $\leftarrow$ & KHLTT & 0.761 & 0.421 & 0.579 & & \\
\hline KHLTT6 & $\leftarrow$ & KHLTT & 0.755 & 0.430 & 0.570 & & \\
\hline KHLTT1 & $\leftarrow$ & KHLTT & 0.755 & 0.430 & 0.570 & & \\
\hline LTT4 & $\leftarrow$ & LTT & 0.809 & 0.346 & 0.654 & \multirow{8}{*}{0.929} & \multirow{8}{*}{0.619} \\
\hline LTT1 & $\leftarrow$ & LTT & 0.793 & 0.371 & 0.629 & & \\
\hline LTT7 & $\leftarrow$ & LTT & 0.770 & 0.407 & 0.593 & & \\
\hline LTT8 & $\leftarrow$ & LTT & 0.761 & 0.421 & 0.579 & & \\
\hline LTT5 & $\leftarrow$ & LTT & 0.767 & 0.412 & 0.588 & & \\
\hline LTT2 & $\leftarrow$ & LTT & 0.774 & 0.401 & 0.599 & & \\
\hline LTT3 & $\leftarrow$ & LTT & 0.785 & 0.384 & 0.616 & & \\
\hline LTT6 & $\leftarrow$ & LTT & 0.834 & 0.304 & 0.696 & & \\
\hline TNTN1 & $\leftarrow$ & TNTN & 0.796 & 0.366 & 0.634 & \multirow{6}{*}{0.912} & \multirow{6}{*}{0.633} \\
\hline TNTN6 & $\leftarrow$ & TNTN & 0.811 & 0.342 & 0.658 & & \\
\hline TNTN3 & $\leftarrow$ & TNTN & 0.789 & 0.377 & 0.623 & & \\
\hline TNTN5 & $\leftarrow$ & TNTN & 0.804 & 0.354 & 0.646 & & \\
\hline TNTN2 & $\leftarrow$ & TNTN & 0.772 & 0.404 & 0.596 & & \\
\hline TNTN4 & $\leftarrow$ & TNTN & 0.802 & 0.357 & 0.643 & & \\
\hline TNPL3 & $\leftarrow$ & TNPL & 0.831 & 0.309 & 0.691 & \multirow{4}{*}{0.868} & \multirow{4}{*}{0.622} \\
\hline TNPL4 & $\leftarrow$ & TNPL & 0.793 & 0.371 & 0.629 & & \\
\hline TNPL2 & $\leftarrow$ & TNPL & 0.767 & 0.412 & 0.588 & & \\
\hline TNPL1 & $\leftarrow$ & TNPL & 0.761 & 0.421 & 0.579 & & \\
\hline TNKT3 & $\leftarrow$ & TNKT & 0.747 & 0.442 & 0.558 & \multirow{4}{*}{0.848} & \multirow{4}{*}{0.582} \\
\hline TNKT1 & $\leftarrow$ & TNKT & 0.740 & 0.452 & 0.548 & & \\
\hline TNKT2 & $\leftarrow$ & TNKT & 0.759 & 0.424 & 0.576 & & \\
\hline TNKT4 & $\leftarrow$ & TNKT & 0.805 & 0.352 & 0.648 & & \\
\hline
\end{tabular}

Note TNTN for Philanthropic responsibility; TNDD for Ethical responsibility; TNPL for Legal responsibility; TNKT for Economic responsibility; KHLTT for Customer-centric; DTNN for Corporate reputation; LTT for Customer loyalty.

Source: own compilation 


\subsection{A structural equation modelling}

We now move to our analysis using structural equation modelling. Figure 2 below presents the results of model testing. All statistical figures satisfy the prerequisite conditions: Chi-square (1.946) statistically significant at 1 per cent level, RMSEA (0.051), CFI (0.918), TLI (0.913).

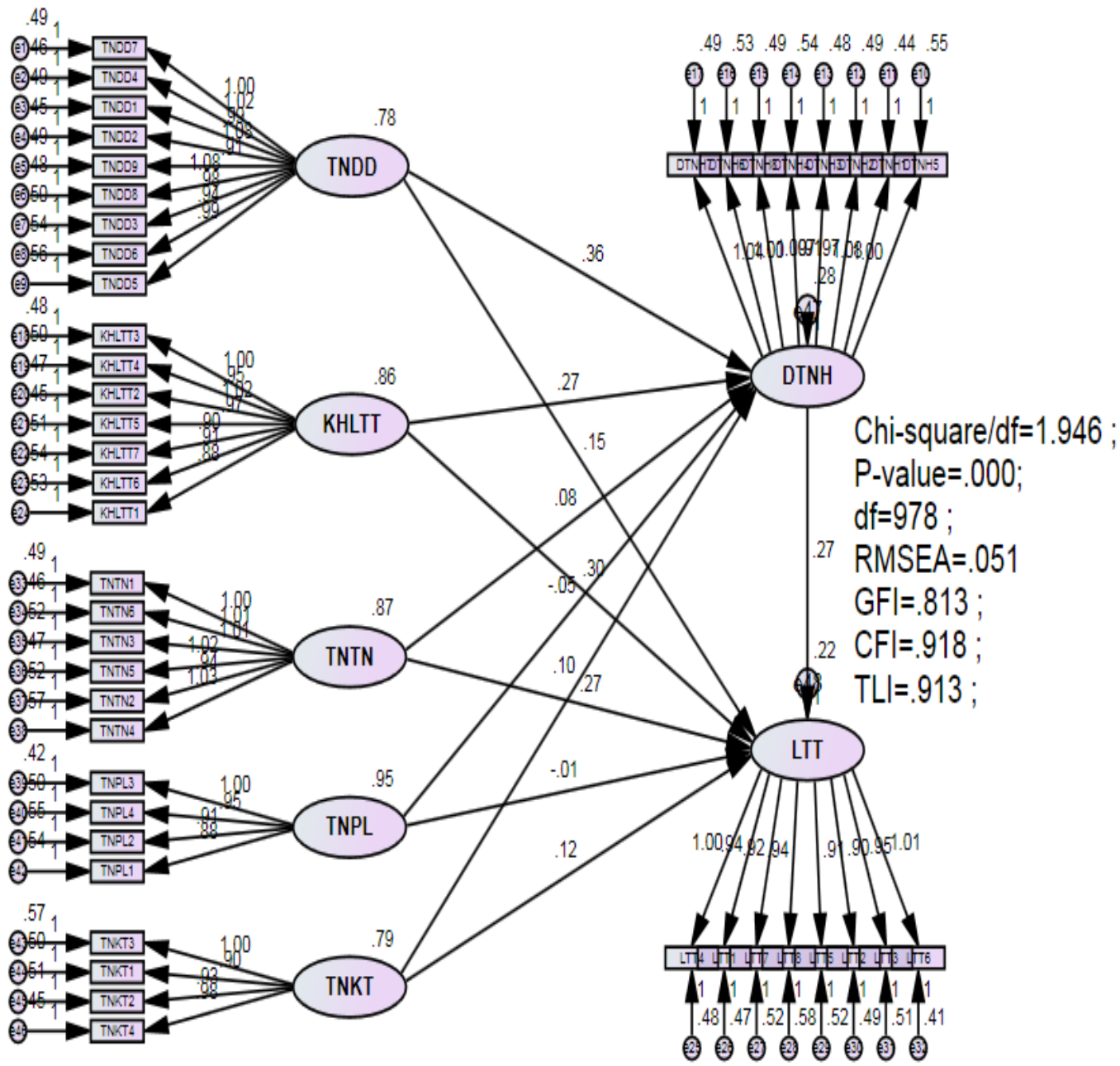

Figure 2. Structure equation modeling

Note $\quad$ TNTN for Philanthropic responsibility; TNDD for Ethical responsibility; TNPL for Legal responsibility; TNKT for Economic responsibility; KHLTT for Customer-centric; DTNH for Corporate reputation; LTT for Customer loyalty.

Source: own compilation

Findings from this study can be summarized as follows.

- First, in relation to the effects of the CSR to customer royalty, findings from this paper confirm that four attributes of the CSR programs from banks have a positive effect on customer loyalty. These attributes include (i) philanthropic responsibility; (ii) ethical responsibility; (iii) economic responsibility; and (iv) customer-centric strategy. Interestingly, findings from this paper fail to confirm the effect of "legal responsibility" aspect of the CSR to customer loyalty in Vietnam. Table 5 presents the estimation of the non-standardized coefficient from SEM. 
Table 5:

Estimation of non-standardized coefficients

\begin{tabular}{|c|c|c|c|c|c|c|}
\hline \multicolumn{2}{|c|}{ Relationship } & $\begin{array}{c}\text { Non-standardized } \\
\text { coefficient }\end{array}$ & $\begin{array}{c}\text { Standardized } \\
\text { coefficient }\end{array}$ & $\begin{array}{c}\text { P- } \\
\text { value }\end{array}$ & Hypothesis testing \\
\hline DTNH & $\leftarrow$ & TNDD & 0.362 & 0.472 & $* * *$ & Accept H2b \\
\hline DTNH & $\leftarrow$ & KHLTT & 0.270 & 0.371 & $* * *$ & Accept H2e \\
\hline DTNH & $\leftarrow$ & TNTN & 0.084 & 0.116 & $* * *$ & Accept H2a \\
\hline DTNH & $\leftarrow$ & TNPL & -0.045 & -0.065 & 0.187 & Reject H2c \\
\hline DTNH & $\leftarrow$ & TNKT & 0.103 & 0.135 & $* * *$ & Accept H2d \\
\hline LTT & $\leftarrow$ & DTNH & 0.270 & 0.259 & $* * *$ & Accept H3 \\
\hline LTT & $\leftarrow$ & TNDD & 0.150 & 0.188 & $* * *$ & Accept H1b \\
\hline LTT & $\leftarrow$ & KHLTT & 0.297 & 0.392 & $* * *$ & Accept H1e \\
\hline LTT & $\leftarrow$ & TNTN & 0.274 & 0.363 & $* * *$ & Accept H1a \\
\hline LTT & $\leftarrow$ & TNPL & -0.006 & -0.009 & 0.845 & Reject H1c \\
\hline LTT & $\leftarrow$ & TNKT & 0.118 & 0.149 & $* * *$ & Accept H1d \\
\hline
\end{tabular}

Note: *** means significant at 1 per cent

Note DTNH for Corporate reputation; LTT for Customer loyalty; TNTN for Philanthropic responsibility; TNDD for Ethical responsibility; TNPL for Legal responsibility; TNKT for Economic responsibility; KHLTT for Customer-centric;

Source: own compilation

- Second, in relation to the effects from the CSR's attributes to corporate reputation, except for "legal responsibility" aspect of the CSR, all other attributes of the CSR are found to positively affect the corporate reputation in Vietnam.

- Third, this study finds a positive effect from corporate reputation to customer loyalty in the banking sector in Vietnam.

\subsection{Robustness analysis using a bootstrap method}

The bootstrap method uses the resampling technique by repeating sampling with replacement 1,000 times. The mean value is calculated after each bootstrap sample, which is then compared with the standardized estimates. Table 6 confirms that the bias statistics are minimal and insignificant, indicating the estimates from our structural equation modelling are highly reliable. As such, we consider that the findings from this paper are robust.

Table 6

Bootstrap method

\begin{tabular}{|c|c|c|c|c|c|c|c|c|}
\hline \multicolumn{3}{|c|}{ Relationship } & SE & SE-SE & Mean & Bias & SE-Bias & C.R \\
\hline DTNH & $\leftarrow$ & TNDD & 0.105 & 0.002 & 0.361 & -0.001 & 0.003 & -0.333 \\
\hline DTNH & $\leftarrow$ & KHLTT & 0.098 & 0.002 & 0.268 & -0.003 & 0.003 & -1.000 \\
\hline DTNH & $\leftarrow$ & TNTN & 0.096 & 0.002 & 0.092 & 0.008 & 0.003 & 2.667 \\
\hline DTNH & $\leftarrow$ & TNPL & 0.032 & 0.001 & -0.045 & 0.000 & 0.001 & 0.000 \\
\hline DTNH & $\leftarrow$ & TNKT & 0.092 & 0.002 & 0.102 & -0.001 & 0.003 & -0.333 \\
\hline LTT & $\leftarrow$ & DTNH & 0.104 & 0.002 & 0.262 & -0.008 & 0.003 & -2.667 \\
\hline LTT & $\leftarrow$ & TNDD & 0.098 & 0.002 & 0.154 & 0.004 & 0.003 & 1.333 \\
\hline LTT & $\leftarrow$ & KHLTT & 0.078 & 0.002 & 0.301 & 0.004 & 0.002 & 2.000 \\
\hline LTT & $\leftarrow$ & TNTN & 0.090 & 0.002 & 0.276 & 0.002 & 0.003 & 0.667 \\
\hline LTT & $\leftarrow$ & TNPL & 0.035 & 0.001 & -0.007 & 0.000 & 0.001 & 0.000 \\
\hline LTT & $\leftarrow$ & TNKT & 0.086 & 0.002 & 0.119 & 0.001 & 0.003 & 0.333 \\
\hline
\end{tabular}

Note $\quad$ TNTN for Philanthropic responsibility; TNDD for Ethical responsibility; TNPL for Legal responsibility; TNKT for Economic responsibility; KHLTT for Customer-centric; DTNN for Corporate reputation; LTT for Customer loyalty.

Source: own compilation 


\section{CONCLUSIONS}

Implementing corporate social responsibility appears to be a new mechanism for firms to maximize their profits, in particular in emerging markets such as Vietnam where the CSR activities have now been widely used from the last decade. The banking sector has been recognized as one of the key sectors contributing significantly to the process of economic growth and development in Vietnam in the last three decades. The sector has since then been facing intense competition due to the integration of the Vietnamese economy into the regional and the world economy. Maintaining customer royalty appears to be a key enabler for the success of the sector in the future.

This study is conducted to examine the impact of the CSR attributes on customer loyalty in the banking sector in Vietnam. Based on Caroll's (1979) pyramid model, customer-centric strategy and bank reputation are added to develop the research model. This paper uses both qualitative and quantitative research techniques to analyze surveyed data on the sample of 386 questionnaires conducted in 2019. Key findings from this study can be summarized as follows.

- First, four CSR attributes, including philanthropic responsibility; ethical responsibility; economic responsibility and customer-centric responsibility, are found to provide positive effects on customer loyalty. In addition, customer perceptions of CSR activities lead to increased bank reputations. Among these factors, philanthropic responsibility receives the most recognition to maintain customer loyalty.

- Second, four CSR attributes, including philanthropic responsibility; ethical responsibility; economic responsibility and customer-centric responsibility, are also found to enhance corporate reputation.

- Third, the reputation of the banks does also provide a positive effect to maintain customer loyalty in the banking sector in Vietnam.

- Fourth, among five attributes from the CSR activities in Vietnam, this paper fails to provide evidence to confirm that legal responsibility does affect customer loyalty in the banking sector.

In summary, results from our analyses demonstrate that philanthropic responsibility has the most significant effect on customer loyalty, followed by customer-centric strategy, ethical responsibility and economic responsibility. It seems that Vietnamese customers have a greater appreciation for philanthropic activities and that such beneficence can improve bank images to gain more loyalty from customers. As such, banks should consciously aim to maximize their CSR activities. CSR activities from the banks should be involved in charitable activities on a national level. Banks should also put efforts in communicating with the customers in relation to their social contributions to the community where they operate.

In addition, the customer-centric strategy has a substantial impact on customer loyalty. As such, banks should focus on creating a positive experience for the customers by maximizing product and service offerings, leading to enhance financial inclusion - a key priority of the Vietnamese government in the next decade. Enhancing financial inclusion requires training programs for customer service personnel to be implemented regularly. In addition, communication skills, problem-solving skills, handling of customer complaints should also receive great attention from the banking sector in the future.

Legal responsibility is the only attribute which does not provide a significant effect on customer loyalty. It can be explained that the banking sector in Vietnam operates under very strict regulations adopted by the State Bank and the Vietnamese Government. As such, customers may not be able to distinguish legal responsibilities between banks. However, this is potentially a short-term effect because Vietnamese people have great belief in the operation of the banking sector in Vietnam without seeing potential risks arising from its operations. In the long term, as more and more incidents regarding risky legal procedures occur, customer's legal awareness is likely to improve. 


\section{ACKNOWLEDGEMENT}

The research is funded by Vietnam National Foundation for Science and Technology Development (NAFOSTED) under grant number 502.01-2019.18

\section{REFERENCES}

Bae, J., \& Cameron, G. T. (2006). Conditioning effect of prior reputation on the perception of corporate giving. Public Relations Review, 32(2), 144-150.

Basdeo, D. K., Smith, K. G., Grimm, C. M., Rindova, V. P., \& Derfus, P. J. (2006). The impact of market actions on firm reputation. Strategic Management Journal, 27(12), 1205-1219.

Berens, G., Van Riel, C. B., \& Van Bruggen, G. H. (2005). Corporate associations and consumer product responses: The moderating role of corporate brand dominance. Journal of Marketing, 69(3), 35-48.

Bhattacharya, C. B., Korschun, D., \& Sen, S. (2009). Strengthening stakeholder-company relationships through mutually beneficial corporate social responsibility initiatives. Journal of Business Ethics, 85(2), 257-272.

Bowen, H. R., \& Johnson, F. E. (1953). Social Responsibility of the Businessman. New York: Harper \& Row.

Caroll, B. A. (1991). The Pyramid of Corporate Social Responsibility. Business Horizon.

Carrigan, M., \& Attalla, A. (2001). The myth of the ethical consumer-do ethics matter in purchase behaviour? Journal of Consumer Marketing, 18(7), 560-578.

Chaudhuri, A., \& Holbrook, M. B. (2001). The chain of effects from brand trust and brand affect to brand performance: the role of brand loyalty. Journal of Marketing, 65(2), 81-93.

Choi, B., \& La, S. (2013). The impact of corporate social responsibility (CSR) and customer trust on the restoration of loyalty after service failure and recovery. Journal of Services Marketing, 27(3), 223-233.

Crespo, A. H., \& del Bosque, I. R. (2005). Influence of corporate social responsibility on loyalty and valuation of

Galbreath, J., \& Shum, P. (2012). Do customer satisfaction and reputation mediate the CSR-FP link? Evidence from Australia. Australian Journal of Management, 37(2), 211-229.

Hsu, K. T. (2012). The advertising effects of corporate social responsibility on corporate reputation and brand equity: Evidence from the life insurance industry in Taiwan. Journal of Business Ethics, 109(2), 189-201.

Jamali, D. (2008). A stakeholder approach to corporate social responsibility: A fresh perspective into theory and practice. Journal of Business Ethics, 82(1), 213-231.

Kotler, P., \& Lee, N. (2005). Best of breed: When it comes to gaining a market edge while supporting a social cause, "corporate social marketing" leads the pack. Social Marketing Quarterly, 11(3-4), 91-103.

Maignan, I. (2001). Consumers' perceptions of corporate social responsibilities: A cross-cultural comparison. Journal of Business Ethics, 30(1), 57-72.

Mandhachitara, R., \& Poolthong, Y. (2011). A model of customer loyalty and corporate social responsibility. Journal of Services Marketing, 25(2), 122-133.

McDonald, S., \& Young, S. (2012). Cross-sector collaboration shaping corporate social responsibility best practice within the mining industry. Journal of Cleaner Production, 37, 54-67.

Nguyen, N., \& LeBlanc, G. (2001). Image and reputation of higher education institutions in students' retention decisions. International Journal of Educational Management, 15(6), 303-311.

Nguyen, T. N., Vo, H. D., and Van, T.H.L (2020). Financial Inclusion and Stability in the Asian Region Using BankLevel Data. Borsa Istanbul Review.Forthcoming.

Oliver, R. L. (1999). Whence consumer loyalty? Journal of Marketing, 63, 33-44.

Pérez, A., del Mar García de los Salmones, M., \& Rodríguez del Bosque, I. (2013). The effect of corporate associations on consumer behavior. European Journal of Marketing, 47(1/2), 218-238.

Reast, J. D. (2005). Brand trust and brand extension acceptance: the relationship. Journal of Product \& Brand Management, 14(1), 4-13.

Turker, D. (2009). Measuring corporate social responsibility: A scale development study. Journal of Business Ethics, 85(4), 411-427.

Van, T.H.L. and Vo, H. D. (2020). Corporate Social Responsibility: A Study on Awareness of Consumers in Vietnam. Review of Pacific Basin Financial Markets and Policies. Forthcoming.

Van, T.H.L., Vo, T.A., Nguyen, T.N. and Vo, H.D. (2019). Financial Inclusion and Economic Growth: An International Evidence. Emerging Markets Finance and Trade.

Van Marrewijk, M. (2003). Concepts and definitions of CSR and corporate sustainability: Between agency and communion. Journal of Business Ethics, 44(2-3), 95-105. 